特 集

\title{
鉄道車両への大容量非接触給電技術
}

\section{High Power Wireless Power Transmission Technologies to Railway Vehicles.}

\author{
近藤 圭一郎 ${ }^{* 1}$
}

Keiichiro KONDO

\begin{abstract}
Wireless power transmission technology can be a simple and frequent high power, such as $300 \mathrm{~kW}$, charging measure to the energy storage device onboard railway vehicle. In this application, higher reactive power should be cared due to the long gap between primary coil and secondary coil on the coils design. Switching loss of the power converters should be looked after by the less switching frequency and zero current switching (ZCS) technologies. In this paper, the author introduces the design method of the coils with less reactive power and presents one of experimental results of a power control method with ZCS technologies by means of scale down experimental model.
\end{abstract}

(2016 年 9 月 20 日受付)

\section{1 緒言}

非接触給電技術は，ケーブル(ワイヤ)等で電気的に 接続して給電することが困難もしくは, 得策では無い 場合の電力供給の方法として有効である。最近では, 電気自動車の一充電走行距離延伸への期待に対して, 手軽で高頻度な充電方法として非接触給電技術に関す る研究開発が盛んに行われている。電気自動車の定置 充電を目指したものとしては, $30 \mathrm{~kW}$ の電磁誘導方式 [1]などが報告されている。また, 位置ずれに強い磁界 共鳴方式を用いた電気自動車へ給電の取り組みも盛ん である[2]。同じ陸上交通機関である鉄道車両は 1 次元 的な移動故に, 電気応用の黎明期である 19 世紀末から, 架線とパンタグラフによる車両への電力供給が実現さ れた。その結果として高性能でエネルギー効率も高い 電気駆動方式が鉄道では発達した。しかし, 架線を含 む電力供給設備(電化設備)は, 線路延長に渡って敷設 する必要があり，イニシャルおよびランニング双方の コストが高くなる課題がある。そのため, 輸送量の少 ない路線では, ディーゼルエンジン駆動を採用し，低 コストに鉄道輸送を実現することが行われる。このよ うな非電化路線においてはディーゼルエンジンに起因 した，排気ガス，振動，騒音，低いエネルギー効率な ごの課題が生じる。これに対して近年では, 蓄電池電 車を導入し, 非電化区間でも電気駆動を実現し, 前述

連絡先： 近藤 圭一郎, $\bar{\top} 263-8522$ 千葉市稲毛区弥生 1-33, 千葉大学工学研究科, e-mail: kkondo@faculty.chiba-u.jp

${ }^{* 1}$ 千葉大学
の課題の解決もしくは低減を図っている[3]。この場合, 車上蓄電装置への充電が不可欠である。例えば，駅の 停車中に蓄電装置を充電する方法が考えられる。これ をパンタグラフと架線によって実現する場合，停車し ながら大電流を流すと，パンタグラフの擦り板と架線 の間の接触抵抗により，これらの発熱・溶断の恐れが ある。また，短い停車時間に，極力短時間でパンタグ ラフの上昇・下降を実施するためには, 架線有無の検 出，パンタ上昇可否の判断，異常検知などを全て自動 で行う必要も出てくる。このようなシステムの煩雑さ を考えた場合，非接触給電とすることで，これらの課 題が軽減され, 高頻度に充電が行える点で優位性があ ると考えられる。これを実現すべき, 筆者らの研究グ ループでは，電化を行わず低コストに鉄道車両の電気 駆動を実現する一方策として 300kW クラスの大容量 非接触給電の技術的可能性について研究を行っている。 具体的には, 非接触給電コイルの無効電力最小化設計 の具体的手順の明確化とその結果として得られる動作 周波数の決定法，車上電力変換装置をゼロ電流スイッ チングにより損失を低減する方法などを明らかとして いる。本稿ではこれらについて記し, 関連技術の進展 に寄与することを目的とする。

\section{2 鉄道車両駆動における大容量非接触給電の諸元}

\section{1 非接触給電容量の検討}

鉄道車両の質量は非電化区間を走行する蓄電池車 両の場合，35～40t と考えられる。最高運転速度を 


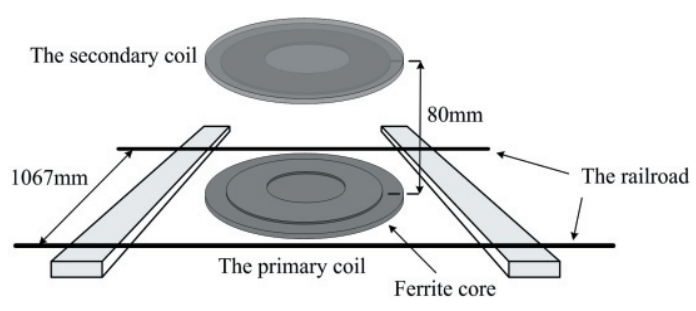

Fig. 1 An example of WPT coils for railway vehicle application.

$72 \mathrm{~km} / \mathrm{h}$ と仮定すると, 車両 1 両の持つ運動エネルギー は,

$$
1 / 2 \times(20[\mathrm{~m} / \mathrm{s}])^{2} \times 40000[\mathrm{~kg}]=8.0 \mathrm{MJ}=2.22 \mathrm{kWh}
$$
となる。

走行抵抗として消費されるエネルギーは運動エネ ルギーの $20 \%$ 程度とすると, 蓄電装置は一駅走行する のに, $2.7 \mathrm{kWh}$ 程度のエネルギーを供給する必要があ る。回生ブレーキによる運動エネルギーの回収を期待 できる場合, 蓄電装置から供給されるエネルギーの 30\%程度の回収が可能である。したがって, 一駅間で 消費するエネルギーは運動エネルギーと等しい約 $2.0 \mathrm{kWh}$ と仮定できる。

非電化路線の駅停車時間は対向列車との離合が無 い場合は 30 秒と仮定する。従って，上記エネルギー をこの停車時間内に充電するには,

$$
2.0 \mathrm{kWh} \div 30 \mathrm{~s}=240 \mathrm{~kW}
$$

となる。

以上から補機電力分や勾配等による余裕分なども見 込んで給電電力の目標として $300 \mathrm{~kW}$ を設定した。すな わち, 給電システムの性能としては, $300 \mathrm{~kW}$ を 1 分以 内の時間供給できる能力があればよい。
地上に設置される一次コイルは Fig. 1 に示すように, 線路間に設置されるため, 概ね $800 \mathrm{~mm}$ 程度の幅に収め る必要がある。なお，本稿で紹介するコイルは，仮想 設計の容易さを考慮して，円形コイルとしていが，実 際には列車の停止位置は数 $10 \mathrm{~cm}$ 程度はずれることを 想定したコイル形状とする必要がある。例えば, $1 〜 2 \mathrm{~m}$ 程度の矩形もしくはレーストラック状のコイルとする のが現実的である。また， 2 つのコイルのメカニカル ギャップは国土交通省令の普通鉄道構造規則などから 80mm と想定している。

\section{3 非接触給電方式と動作周波数}

$300 \mathrm{~kW}$ 程度の非接触給電では, 電力変換器を含め た送電効率の向上，放射磁界の防止などの観点から 電磁誘導方式を前提とした。動作周波数は一般にコ イル寸法 (総鎖交磁束数), 無効電力の大きさ, 電力 変換回路の損失などを決定する重要なパラメータで ある。停車中の非接触給電では, Fig.2 に示すように, 車両駆動用インバータを受電側電力変換回路として 利用することを想定している。車両駆動用インバー タは, $3.3 \mathrm{kV}-1.2 \mathrm{kA}$ 定格の IGBT を用い, スイッチン グ周波数は損失低減の観点から最高で $1.0 \mathrm{kHz}$ 程度 である。後述のように，損失低減のためゼロ電流ス イッチング (Zero Current Switching : ZCS) を行う方 式を検討しているが，スイッチングタイミングのず れにより, 必ずしも ZCS が達成されない場合もあり 得る。そのような場合も想定し, 非接触給電の動作 周波数としては，2.0〜 3.0kH が適切と考えられる。

2.2 コイルの寸法
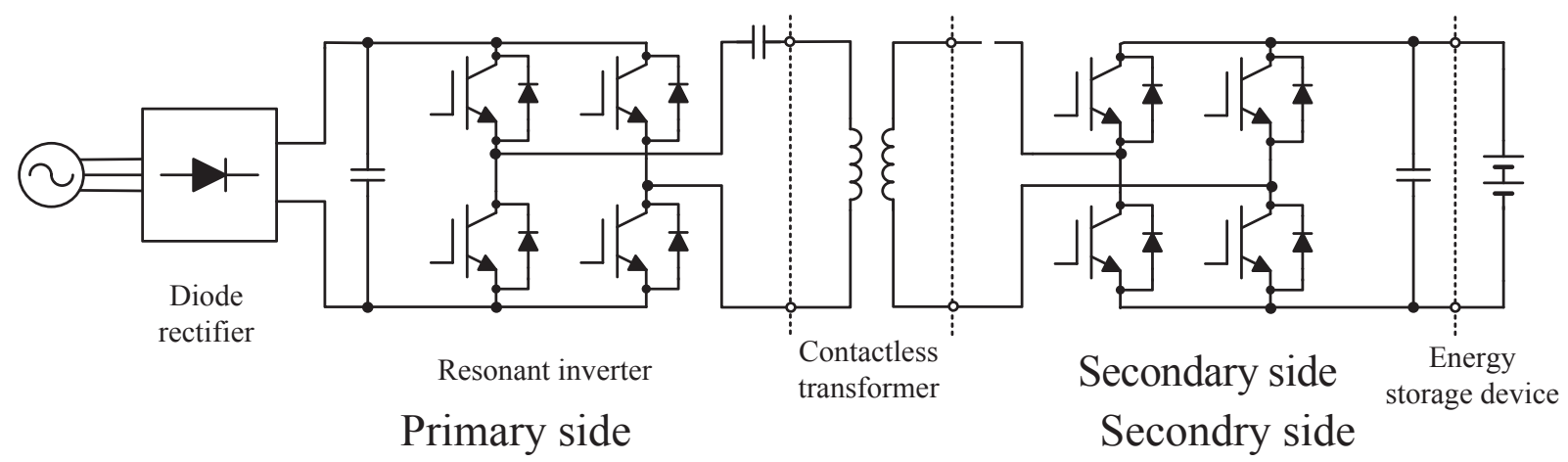

Fig. 2 A system configuration of power conversion circuit. 


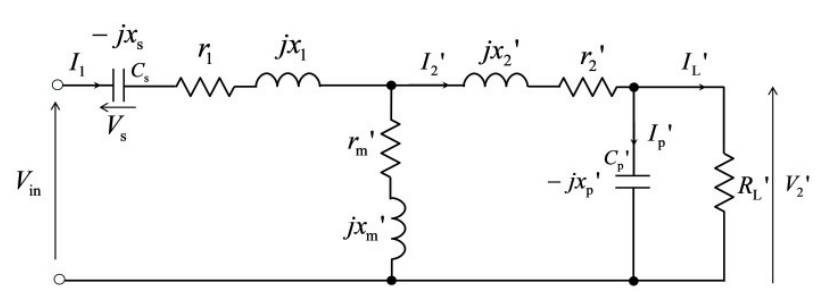

Fig. 3 Equivalent circuit with SP type compensation capacitors.

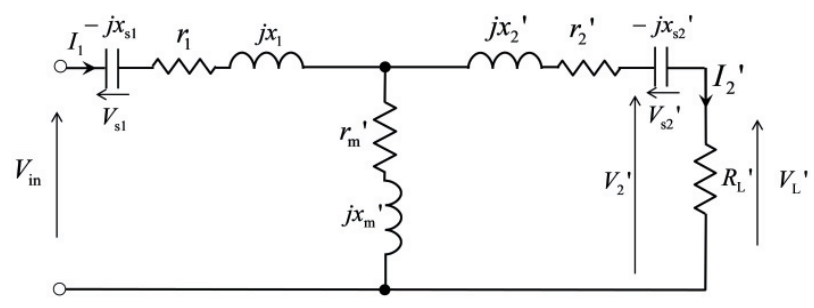

Fig. 4 Equivalent circuit with SS type compensation capacitors.

Fig. 2 に示すように, 電力変換回路としては, 将来 の双方向給電へ拡張性を考慮するならば，地上，車 上とも自励式電圧形インバータを想定するのが技術 的には妥当である。この場合, 送電電力制御は蓄電 デバイスが搭載されている車両側で行うことが好ま しいことから，例えば，車上の DC/DC チョッパ回 路で電圧制御によって行う方法が考えられる。した がって, 地上側変換回路は一定電圧・一定周波数で 動作する CVCF 電源として動作させる。車上の電力 変換回路でゼロ電流スイッチングを行うことで，ス イッチング損失の低減を期する $[4]$ 。鉄道車両用非接 触給電では送電電力が大きく, かつギャップ長も長 いことから, 無効電力が大きくなる。無効電力補償 にはコイルの一次側, 二次側とにもコンデンサを接 続することで補償を行う方式が知られている。ギャ ップ長の長い大容量非接触給電では, コンデンサの 電流容量や耐圧の観点からも, 無効電力を低減する 設計が重要である。給電システム全体としての無効 電力低減の観点からは, 出力側は補償コンデンサを 並列接続する Fig. 3 のような SP 方式が有利である。 しかし，電圧形インバータは電圧源として動作する ことから，これを出力側に接続する場合には, Fig. 4 に示すような, 二次側も補償用コンデンサが直列接 続された SS 方式とする必要がある。

\section{3 大容量コイルの仮想設計 [5]}

\section{1 設計条件}

Fig. 1 に示したような形状で, 一次電源電圧・電流 が $1500 \mathrm{~V}-200 \mathrm{~A}-300 \mathrm{~kW}$ の非接触給電システム用コ イルの仮想設計を行なった。補償用コンデンサの接続 方式は Fig. 3 および Fig. 4 に示した SP 方式および SS 方式の両方で検討を行った。各方式のコイルの一次側, 二次側の無効電力 $Q_{1 \mathrm{SP}}, Q_{2 \mathrm{sP}}, Q_{\mathrm{ISS}}, Q_{2 \mathrm{ss}}$ は以下の式に 示すように, コイルの一次 (二次) リアクタンス $X$ の 関数である。

$$
\begin{gathered}
Q_{1 \mathrm{SP}}=\left(1-k^{2}\right) X \frac{P^{2}}{V_{\mathrm{in}}^{2}} \\
Q_{2 \mathrm{SP}}=\frac{V_{\mathrm{in}}{ }^{2}}{k^{2} X} \\
Q_{1 \mathrm{SS}}=X \frac{P^{2}}{V_{\mathrm{in}}{ }^{2}} \\
Q_{2 \mathrm{SS}}=\frac{V_{\mathrm{in}}{ }^{2}}{k^{2} X}
\end{gathered}
$$

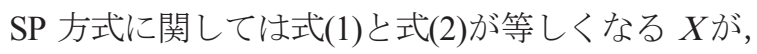
SS 方式に関しては式(3)と式(4)が等しくなる $X$ が，そ れぞれ一次側および二次側合計の無効電力を最小化す る $X$ である。それらをそれぞれ $X_{\mathrm{SP}}, X_{\mathrm{SS}}$ とすると, 以 下で示される。

$$
\begin{gathered}
X_{S P}=\frac{V_{\text {in }}^{2}}{k \sqrt{1-k^{2}} P} \\
X_{S S}=\frac{V_{\text {in }}^{2}}{k P}
\end{gathered}
$$

次項で記述する設計結果として得られた定数類を 用いて，無効電力を最小化する条件から動作周波数を 決めることができる。

鉄心はフェライトコアを想定し, 最高磁束密度は $0.4 \mathrm{~T}$ とした。

\section{2 設計結果}

$300 \mathrm{~kW}$ クラスコイルを FEM による磁場解析などを 用いて設計した結果を，SP 方式については Table1 と Fig. 5 に, SS 方式については Table 2 と Fig. 6 にそれぞ 


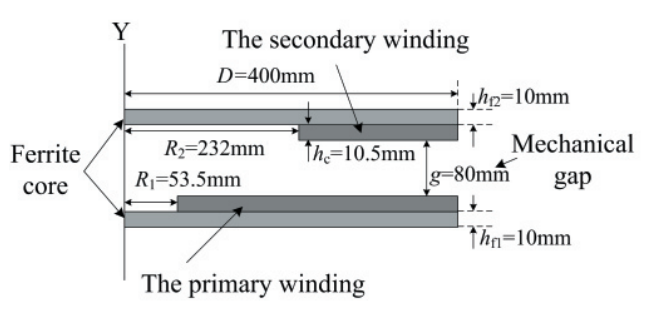

Fig. 5 An analysis model of coils for the SP type.

Table 1 Analytical results of coils for the SP type.

\begin{tabular}{|c|c|c|c|c|}
\hline$L_{1}[\mathrm{mH}]$ & $L_{2}[\mathrm{mH}]$ & $k$ & $r_{1}[\mathrm{~m} \Omega]$ & $r_{2}[\mathrm{~m} \Omega]$ \\
\hline 0.908 & 0.456 & 0.705 & 11.7 & 7.94 \\
\hline
\end{tabular}

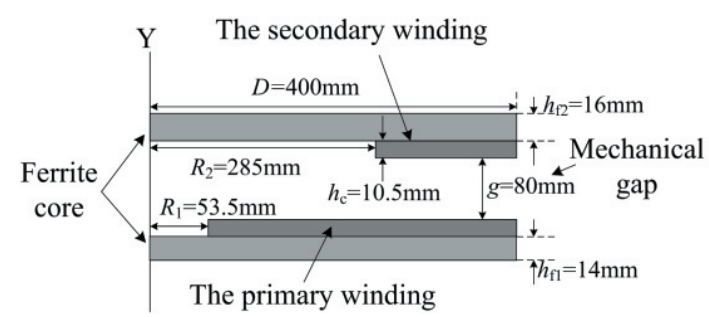

Fig. 6 An analysis model of coils for the SS type.

Table 2 Analytical results of coils for the SS type.

\begin{tabular}{|c|c|c|c|c|}
\hline$L_{1}[\mathrm{mH}]$ & $L_{2}[\mathrm{mH}]$ & $k$ & $r_{1}[\mathrm{~m} \Omega]$ & $r_{2}[\mathrm{~m} \Omega]$ \\
\hline 0.908 & 0.255 & 0.641 & 11.7 & 5.91 \\
\hline
\end{tabular}

Table 3 Analytical results of coils.

\begin{tabular}{|c|c|c|}
\hline & SP & SS \\
\hline$V_{\text {in }}[\mathrm{V}]$ & \multicolumn{2}{|c|}{1500} \\
\hline$I_{1}[\mathrm{~A}]$ & 201 & 201 \\
\hline$V_{\mathrm{s}}, V_{\mathrm{s} 1}[\mathrm{~V}]$ & 1497 & 2985 \\
\hline$I_{2}[\mathrm{~A}]$ & 284 & 297 \\
\hline$V_{2}[\mathrm{~V}]$ & 1502 & 1597 \\
\hline$P_{\text {in }}[\mathrm{kW}]$ & 301 & 301 \\
\hline$P_{\text {out }}[\mathrm{kW}]$ & 300 & 300 \\
\hline$Q_{1}[\mathrm{kVar}]$ & 301 & 600 \\
\hline$Q_{2}[\mathrm{kVar}]$ & 303 & 367 \\
\hline$B_{1}[\mathrm{~T}]$ & 0.30 & 0.47 \\
\hline$B_{2}[\mathrm{~T}]$ & 0.30 & 0.41 \\
\hline
\end{tabular}

れ示す。また, 各部の電圧, 電流, 無効電力等を SP 方式と SS 方式で比較したものを Table 3 に示す。

なお，巻線の諸元は SP 方式が一次側 33T, 二次側 13T, SS 方式が一次側 33 Turn, 二次側 11 Turn, 占積 率はいずれも 0.61 である。

これらの結果から分かるように, コイルとして見た 場合は SP 方式の方が SS 方式に比べ, 軽量化の点およ

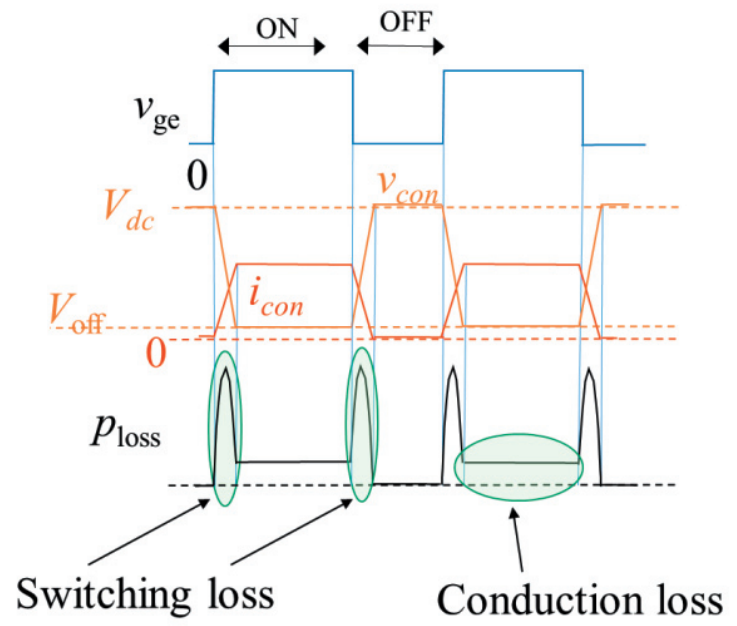

Fig.7 Loss of power semiconductor switching device.

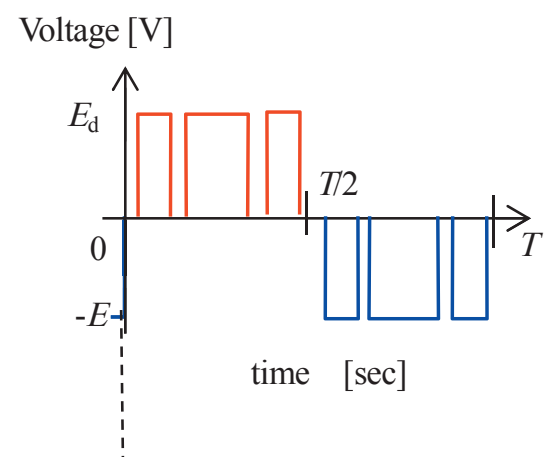

Fig. 8 Voltage waveform of multi plus PWM.

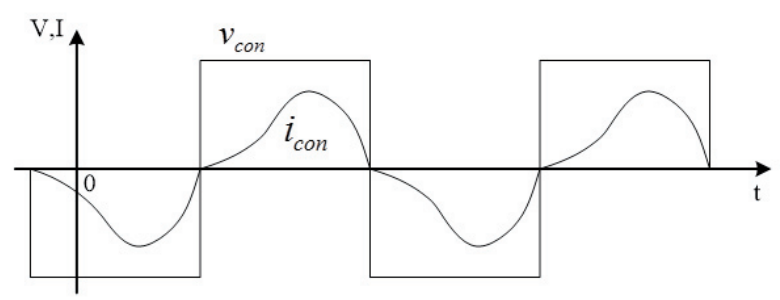

Fig. 9Example wave form of secondary voltage $V_{\text {con }}$ and secondary current $i_{\text {con }}$ in ZCS.

び一次側補償コンデンサ電圧の面で有利であるといえ る。式(5)および式(6)に設計結果から得られた定数類を 用いてそれぞれの動作周波数を求めると, SP 方式では $2.6 \mathrm{kHz}, \mathrm{SS}$ 方式では $2.0 \mathrm{kHz}$ となった。この結果から, 電力変換回路の損失低減の観点からは SS 方式の方が 好ましいと言える。

\section{ZCS による電力変換システムの構成例 [4]}

4.1 回路構成と制御方式 
鉄道車両への非接触給電システムでは，大容量であ るため, 電力変換回路の損失低減に留意した設計が重 要となる。パワー半導体スイッチングデバイスの損失 は Fig. 7 に示すように, 主にはスイッチング損失と導 通損失に分けられる。導通損失は使用するデバイスの 特性により決定される。トータルのスイッチング損失 は一般にスイッチング周波数を低減することで低減が 可能である。そこで, 特に小型軽量化の要求の強い, 車上(二次側)の電力変換回路は, 一般に行われる Fig. 8 のような多パルスのパルス幅変調 (Plus Widths Modulation : PWM)方式ではなく, 出力電圧基本波周期 に一つのパルスを出力する方式を用いる。さらには,

Fig. 9 に示すような, ちようど出力電流が 0 のタイミ ングで，デバイスの ON,OFF を行うことでスイッチン グ損失を低減するゼロ電流スイッチング(Zero Current Switching : ZCS)を適用する方式が考えられる。

そこで, Fig. 9 に示す実験回路を用いて, 二次側電 力変換回路を ZCS で動作させる $1 \mathrm{~kW}$ クラスのミニモ デルシステムを構成し実験を行った。実験システムの 構成を Fig. 10 に示す。

蓄電装置の充電電力制御は車上で行うことから二 次側の蓄電素子に $\mathrm{DC} / \mathrm{DC}$ チョッパを設置して行うべ きであるが，今回は二次側電力変換回路の効率向上を 目指したZCS の検証を主眼に置いていることから, 電 力制御は一次側に接続したインバータにより行う方法 にて実験を実施した。Fig. 11 に一次側インバータの電 力制御系のブロック図を示す。電力指令值 $P^{*}$ を二次側
インバータの直流電圧 $V_{\mathrm{d}}$ で除したものを, 一次側イン バータの電流実効值指令值 $i_{\text {conrms }}{ }^{*}$ とする。これと実際 の偏差を取り，PI補償したものを，フィードフォワー ド電圧成分 $V_{\mathrm{sff}}$ を加え, 一次側インバータの出力電圧 指令值 $V_{\mathrm{s}}^{*}$ が生成される。二次側の電力変換回路では Fig. 10 に示す ZCS を行う。

\subsection{ZCS による電力伝送実験結果}

Fig. 9 のシステムにて，概ね $1 \mathrm{~kW}$ の電力伝送実験を 行った場合の実験結果を Fig. 12 に示す。一次電圧 $v_{\mathrm{s}}$ と一次電流 $i_{\mathrm{s}}$ は同時に 0 にはなっていないが, 二次電 圧 $v_{\text {con }}$ と二次電流 $i_{\text {con }}$ は同時に 0 になっており, ZCS が実現されていることがわかる。Table 4 は二次側電力 変換回路のパルスモードを多パルス PWM(正弦波-三 角波比較 PWM)，1 パルスモード，およびZCS で動作 させた場合の二次側電力変換回路の効率を比較したも のである。この結果から，ZCS は三つの方式で最も効 率が高く, スイッチング損失を低減した効果が出てい るものと考えられる。

\section{5 結言}

本稿では鉄道車両への給電を想定した大容量非接 触給電システムについて，これまでの筆者らの検討結 果を交えて記した。具体的には鉄道車両駆動用非接触 $300 \mathrm{~kW}$ 給電コイルの設計法, およびゼロ電流スイッチ ング $(\mathrm{ZCS})$ を用いた電力変換回路制御方式とその $1 \mathrm{~kW}$

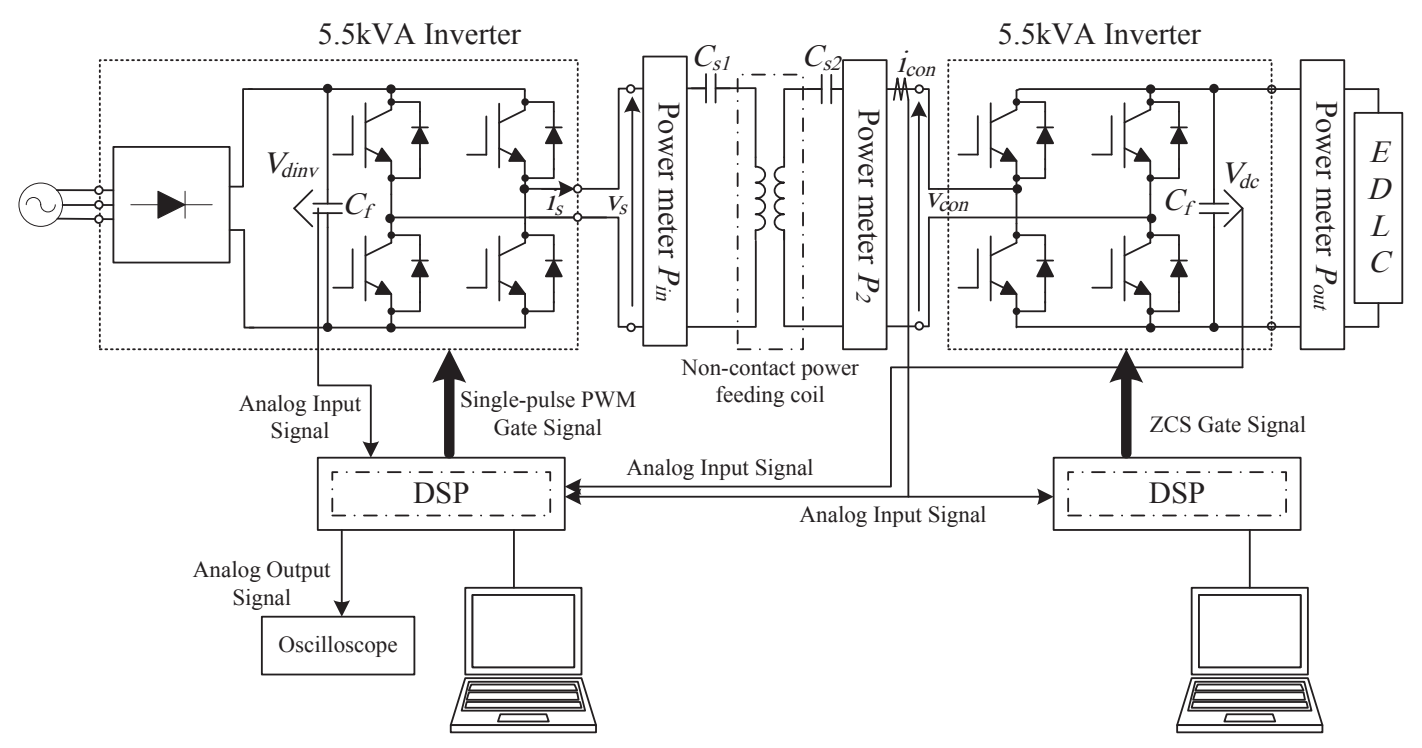

Fig. 10 An experimental setup for ZCS control on the secondary side power converter. 
クラス実験システムでの実験結果について紹介した。 大容量コイルの交流抵抗特性や，車上での電力制御シ ステム構成などを含め, 具体的な実システムの設計検

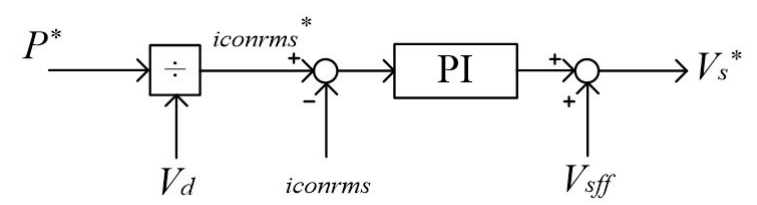

Fig. 11 A block diagram of power control on the primary side power converter.

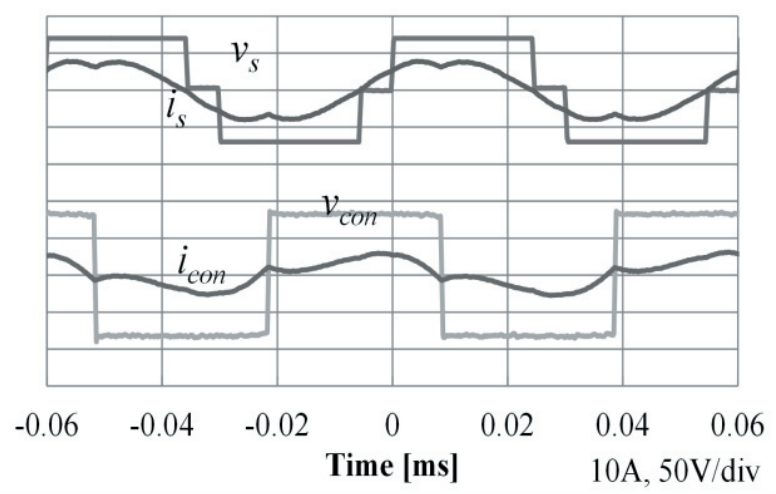

Fig. 12 Experimental test result of power conversion with ZCS.

Table 4 Experimental test results of loss on coils and

\begin{tabular}{|c|c|c|c|}
\hline \multicolumn{4}{|c|}{ secondary power converter. } \\
\hline & $P_{\text {in }}[\mathrm{W}]$ & $P_{\text {out }}[\mathrm{W}]$ & $\begin{array}{c}\text { Coils and } \\
\text { secondary } \\
\text { inverter } \\
\text { efficiency [\%] }\end{array}$ \\
\hline $\begin{array}{c}\text { Multi } \\
\text { plus } \\
\text { PWM }\end{array}$ & 1271 & 1034 & $\mathbf{8 1 . 3 5}$ \\
\hline $\begin{array}{c}\text { Single } \\
\text { plus } \\
\text { PWM }\end{array}$ & 1175 & 985 & $\mathbf{8 3 . 8 3}$ \\
\hline $\begin{array}{c}\text { Single } \\
\text { plus } \\
\text { ZCS }\end{array}$ & 1146 & 988 & $\mathbf{8 6 . 2 1}$ \\
\hline
\end{tabular}

討が今後の課題である。また, 車上蓄電装置の容量低 減のためには, 移動給電が有効な方策であり, これに ついても検討を進めている。こちらについては文献[6] などを参照されたい。

\section{参考文献}

[1] 藤田敏博，金子裕良，阿部茂，直列および並列共振コン デンサを用いた非接触給電システム，電気学会論文誌 D 127 巻 2 号, pp.174-180, 2007.

[2] 居村岳広，岡部浩之，内田利之，堀洋，共振時の電磁 界結合を利用した位置ずれに強いワイヤレス電力伝送

ー磁界型アンテナと電界型アンテナー. 電気学会論文誌D（産 業応用部門誌） Vol. 130, No. 1， pp.76-83.

[3] Y.Kono, N.Shiraki, H.Yokoyama, R.Furuta Catenary and storage battery hybrid system for electric railcar series EV-E301, Proceedings on International Power Electronics Conference (IPEC-Hiroshima 2014 - ECCE-ASIA), pp. 2120 $2125,2014$.

[4] 北澤智志, 山本浩平 近藤圭一郎, 柏木孝行, 非接触給電 システムの電力変換回路における ZCS 動作と伝送電力 制御法, 電気学会半導体電力变換研究会資料 SPC13-096, pp.31-36, 2013.

[5] Kohei Yamamoto, Satoshi Kitazawa*, Takayuki Kashiwagi, Keiichiro Kondo*, A Study on the Circuit Configuration with Capacitors to Compensate the Power Factor for High-Power Contactless Power Transformer. Proceedings of ICEMS2013(CD-ROM), 2013.

[6] Shogo Shibata; Febry Pandu Wijaya, Keiichiro Kondo, A study on the transmission power in dynamic contactless power transmission, Proceedings of IEEE International Conference on Industrial Technology (ICIT), pp. 245 -250, 2016. 